\title{
INFLUENCE OF TRAP COLOUR, DESIGN AND HEIGHT ON CATCH OF FLYING CLOVER ROOT WEEVIL ADULTS
}

\author{
S. HARDWICK ${ }^{1}$ and B. HARENS ${ }^{2}$ \\ ${ }^{1}$ AgResearch, PO Box 60, Lincoln, New Zealand \\ ${ }^{2}$ AgResearch, Ruakura Research Centre, Private Bag 3123, \\ Hamilton, New Zealand
}

Corresponding author: scott.hardwick@agresearch.co.nz

\begin{abstract}
Adult clover root weevil (Sitona lepidus, CRW) catches on sticky traps of different colours, design and height were evaluated in two field experiments carried out on the outskirts of Hamilton in the summer of 1999-2000. In Experiment 1, yellow cylinder traps placed at a height of $1200 \mathrm{~mm}$ caught the most CRW. In Experiment 2, both white and yellow cylinder traps placed at a height of $1200 \mathrm{~mm}$ were equally attractive to CRW adults. In both experiments, fewer CRW adults were caught on cylinder traps of all colours set $400 \mathrm{~mm}$ above the ground. Cylinder traps painted red, green and blue and set $1200 \mathrm{~mm}$ above the ground caught similar numbers of insects to traps of all colours set at $400 \mathrm{~mm}$. In Experiment 2, flat traps with a sticky surface that was parallel to the ground caught very few weevils irrespective of their colour and height. Keywords: Sitona lepidus, flight, dispersal, cylinder sticky trap, flat sticky trap, colour, height.
\end{abstract}

\section{INTRODUCTION}

Clover root weevil (Sitona lepidus Gyllenhal (Coleoptera: Curculionidae)) (CRW) was first discovered in dairy pastures in Waikato in 1996 (Barratt et al. 1996). Subsequent investigations revealed it had spread over an area of 200,000 ha with two epicentres of infestation, one north of Auckland and the other in the Waikato/coastal Bay of Plenty area, and was unable to be eradicated (Barker et al. 1996). Since 1996, CRW has spread at an average rate of ca $35 \mathrm{~km} /$ year and now occurs throughout the North Island (Hardwick et al. 2004; Eerens et al. 2005). Clover root weevil has also been detected in the South Island, but as of February 2007 it appeared to be limited to small, discrete populations in Richmond and the Rai Valley in the Nelson region, and immediately northwest of Christchurch (Phillips et al. 2007).

Whilst it is likely some CRW dispersal into previously uninfested regions has been human assisted, the vast majority has probably been through adult flight. Dispersal flights are made by CRW adults during late spring-summer (Stein \& Rezwani 1973; S. Hardwick \& P.J. Addison, unpubl. data). Interest in the flight behaviour of CRW has increased following the introduction of the Irish strain of Microctonus aethiopoides (Hymenoptera: Brachonidae) to New Zealand (Gerard et al. 2007) since the ability of the parasitoid to rapidly disperse will largely depend on the extent to which eggs and larvae of the parasitoid can be dispersed via flights of infected CRW adults.

Sticky flight traps placed in pastures may be useful for measuring rates of parasitism in flying weevils, and may also be helpful in predicting if newly established pastures are at risk of being rapidly re-invaded by CRW to assist in making sound pest management decisions. Previously, dispersal flights by Argentine stem weevil (Listronotus bonariensis (Kuschel) (Coleoptera: Curculionidae)) and lucerne weevil (Sitona discoideus Gyllenhal (Coleoptera: Curculionidae)) in New Zealand have been monitored using bright yellow cylindrical sticky traps (e.g. Pottinger 1966; Goldson et al. 1984; Barker et al. 1989). 
However, the catch rate of some weevil species, such as West Indian sweet potato weevil (Euscepes postfasciatus (Fairmaire) (Coleoptera: Curculionidae)) (Nakamoto \& Kuba 2004) and pecan weevil (Curculio caryae (Horn) (Coleoptera: Curculionidae)) (Tedders et al. 1996), was significantly greater using traps that were not yellow. In other studies, trap colour did not influence weevil catch rates (e.g. Hunt \& Raffa 1991; Kalleshwaraswamy et al. 2006). The height and orientation of trapping surfaces can also influence capture rates (e.g. Riley \& Schuster 1994; Smart et al. 1997).

This study investigated the influence of sticky trap colour, height and trapping surface orientation on capture rates of CRW adults to optimise the design of sticky traps for monitoring of CRW flights.

\section{MATERIALS AND METHODS}

Two experiments were conducted in the summer of 1999/2000. The timing of the experiments coincided with the period in which clover root weevil adults were known to undertake dispersal flights (S. Hardwick \& P.J. Addison, unpubl. data). In both experiments, CRW flight activity was monitored at AgResearch Ruakura on the outskirts of Hamilton. The study areas and the surrounding environs were ryegrass (Lolium perenne) and white clover (Trifolium repens) paddocks. The aspect was flat and there were no nearby hedges, trees or other structures that might have influenced CRW flight behaviour.

\section{Experiment 1}

Experiment 1 was conducted from 26 November 1999 to 5 January 2000. The flight traps consisted of a pair of $300 \times 110 \mathrm{~mm}$ diameter cylinders mounted on a stake, one above the other, 400 and $1200 \mathrm{~mm}$ above the ground. Both cylinders on each trap were painted the same colour and were covered with a transparent plastic sheet coated with adhesive (Fly control adhesive, Garrick Trading Co Ltd). There were five trap colours, blue, green, red, white or yellow, and ten replicates of each trap were used, giving 50 traps in total. Traps were laid out in a grid of five rows of 10, with each row containing two replicates of each colour. Within each row the position of each trap was assigned completely at random. Traps were placed $10 \mathrm{~m}$ apart within rows, with $15 \mathrm{~m}$ between rows.

\section{Experiment 2}

Experiment 2 was conducted from 20 January-21 February 2000. The two designs of flight trap tested were cylinder traps (described above) and flat traps. Flat traps consisted of a pair of $210 \times 300 \mathrm{~mm}$, coloured corflute sheets mounted so that the trapping surface was parallel to the ground, and either $250 \mathrm{~mm}$ or $1200 \mathrm{~mm}$ above it. The lower trapping surface was attached to the bottom of an upturned wire milk crate, while the upper trapping surface was mounted on a stake and held in place using clips and a wire loop. The upper surface of each trapping surface was coated in Stickem ${ }^{\circledR}$. The colour treatments used were the same as in Experiment 1. Five replicates of each trap design and colour (10 treatments) were used giving 50 traps in total. Traps were laid out in a grid of five rows of ten, with each row containing a flat and a cylinder trap of each colour. Within rows, cylinder traps were alternated with flat traps, but the five colours were assigned in a completely random manner. Traps were laid out $15 \mathrm{~m}$ apart with $15 \mathrm{~m}$ between rows.

In both experiments, traps were inspected daily and any CRW adults present were counted and removed. The sticky trapping surfaces were replaced at approximately weekly intervals. Catch data were square root transformed and statistically analysed using a split plot ANOVA with colours being main plot treatments, heights being subplot treatments and with five blocks (rows). 


\section{Experiment 1}

\section{RESULTS}

Both colour and height significantly influenced the catch of CRW adults (Table 1). Significantly more weevils were caught on yellow traps placed at $1200 \mathrm{~mm}$ than on traps of any other colour or any traps at $400 \mathrm{~mm}(\mathrm{P}<0.05)$ during the 42 day trapping period. During the trial, it was also noted that traps set at $400 \mathrm{~mm}$ tended to more rapidly accumulate dust than those at $1200 \mathrm{~mm}$.

\section{Experiment 2}

Clover root weevil catch data for the cylinder traps in Experiment 2 were similar to those observed in Experiment 1 (Table 2). Yellow and white coloured traps caught more weevils than red, green or blue traps $(\mathrm{P}<0.001)$ (Table 2$)$. The greatest numbers of weevils were caught in yellow or white cylinder traps and set at $1200 \mathrm{~mm}(\mathrm{P}<0.05)$, whilst the least were found in red, green and blue traps set at $400 \mathrm{~mm}$. Yellow and white traps at $400 \mathrm{~mm}$ were of intermediate effectiveness.

Results from Experiment 2 suggested that flat traps caught fewer CRW adults than cylinder traps (Table 2). However, due to the alternating layout of cylinder and flat traps a direct statistical comparison of the data was not possible. A similar number of weevils $(\mathrm{P}>0.05)$ was caught using flat traps irrespective of their colour or the height that they were set at (Table 2). As was observed in Experiment 1, traps of both designs set at $400 \mathrm{~mm}$ in height accumulated dust and debris more rapidly than those set at $1200 \mathrm{~mm}$.

TABLE 1: Mean number of clover root weevil adults caught per trap over the period of 26 November 1999-5 January 2000 on different coloured cylindrical sticky traps at heights of $400 \mathrm{~mm}$ or $1200 \mathrm{~mm}$ in Experiment 1. Values presented are square root transformed data with back transformed means in parentheses.

\begin{tabular}{lcccccc}
\hline \multirow{2}{*}{ Trap height } & \multicolumn{5}{c}{ Trap colour } & $\begin{array}{c}\text { Height } \\
\text { mean }\end{array}$ \\
\cline { 2 - 6 } & white & red & yellow & green & blue & m \\
\hline $400 \mathrm{~mm}$ & $2.9(8.4)$ & $1.7(3.0)$ & $2.7(7.6)$ & $1.9(3.7)$ & $1.8(3.2)$ & $2.2(4.9)$ \\
$1200 \mathrm{~mm}$ & $3.4(11.5)$ & $2.2(4.9)$ & $4.2(18.3)$ & $2.5(6.4)$ & $2.0(4.0)$ & $2.9(8.3)$ \\
Colour mean & $3.1(9.9)$ & $1.9(3.9)$ & $3.5(12.4)$ & $2.2(5.0)$ & $1.9(3.6)$ & \\
LSD $(\mathrm{P}<0.05)$ & Colour means & 0.4 & & & \\
& Height means & 0.3 & & \\
& Height $\times$ colour means & 0.6 & heights within colours \\
& Height $\times$ colour means & 0.6 & all other comparisons \\
\hline
\end{tabular}

\section{DISCUSSION}

Yellow or white cylinder traps mounted $1200 \mathrm{~mm}$ above the ground are the most suitable for monitoring CRW flights. The yellow cylinder traps previously used to study Argentine stem weevil and lucerne weevil flights (e.g. Pottinger 1966; Goldson et al. 1984; Barker et al. 1989) should thus also be suitable for monitoring CRW flights. Prokopy \& Owens (1983) suggested that attraction to yellow is characteristic of all herbivorous insects. Experiment 1 clearly demonstrated that yellow traps were superior to traps of other colours. However, in Experiment 2 white traps were as effective at trapping CRW adults as yellow traps. Cabbage seed weevil (Ceutorhynchus assimilis (Paykull)(Coleoptera: Curculionidae)) has been reported as being attracted to traps that are yellow and white (Goos et al. 1976; Laska et al. 1986), yellow and green (Buechi (1990) as cited in Smart et al. 1997) or yellow only (Smart et al. 1997). Attraction to a particular colour may also be influenced by the surroundings (Kirk 1984). While the study site remained superficially similar in appearance between the two experiments, it is probable that its vegetative composition changed slightly, perhaps due to seasonal effects and changes in soil nutrient status. 
TABLE 2: Mean number of clover root weevil adults caught per trap over the period of 20 January-21 February 2000 on different coloured cylindrical and flat sticky traps at heights of $400 \mathrm{~mm}$ or $1200 \mathrm{~mm}$ in Experiment 2. Values presented are square root transformed data with back transformed means in parentheses.

\begin{tabular}{|c|c|c|c|c|c|c|}
\hline \multirow[b]{2}{*}{ Trap height } & \multicolumn{5}{|c|}{ Trap colour } & \multirow{2}{*}{$\begin{array}{l}\text { Height } \\
\text { mean }\end{array}$} \\
\hline & white & red & yellow & green & blue & \\
\hline \multicolumn{7}{|l|}{ Cylinder traps } \\
\hline $400 \mathrm{~mm}$ & $3.1(9.6)$ & $1.4(1.9)$ & $3.9(15.2)$ & $1.5(2.2)$ & $0.5(0.2)$ & $2.1(4.4)$ \\
\hline $1200 \mathrm{~mm}$ & $4.924 .0)$ & $2.3(5.3)$ & $5.4(29.6)$ & $2.5(6.2)$ & $1.7(2.9)$ & $3.4(8.3)$ \\
\hline Colour mean & $4.0(16.0)$ & $1.9(3.7)$ & $4.7(22.1)$ & $2.0(4.0)$ & $1.1(1.2)$ & \\
\hline \multirow[t]{4}{*}{$\operatorname{LSD}(\mathrm{P}<0.05)$} & \multicolumn{2}{|c|}{ Colour mean } & 0.4 & & & \\
\hline & \multicolumn{2}{|c|}{ Height mean } & 0.5 & & & \\
\hline & \multicolumn{2}{|c|}{ Height $\times$ colour mean } & 1.0 & \multicolumn{3}{|c|}{ heights within colours } \\
\hline & \multicolumn{2}{|c|}{ Height $\times$ colour mean } & 0.8 & \multicolumn{3}{|c|}{ all other comparisons } \\
\hline \multicolumn{7}{|l|}{ Flat traps } \\
\hline $400 \mathrm{~mm}$ & $1.8(3.2)$ & $1.4(1.9)$ & $1.9(3.7)$ & $1.5(2.2)$ & $1.7(2.9)$ & $1.6(2.5)$ \\
\hline $1200 \mathrm{~mm}$ & $1.6(2.5)$ & $1.5(2.2)$ & $1.6(2.5)$ & $1.3(3.2)$ & $1.7(2.9)$ & $1.5(2.2)$ \\
\hline Colour mean & $1.7(2.9)$ & $1.5(2.2)$ & $1.7(2.9)$ & $1.4(1.9)$ & $1.7(2.9)$ & \\
\hline \multirow[t]{4}{*}{ LSD $(\mathrm{P}<0.05)$} & \multicolumn{2}{|c|}{ Colour mean } & 0.6 & & & \\
\hline & \multicolumn{2}{|c|}{ Height mean } & 0.7 & \multirow{2}{*}{\multicolumn{3}{|c|}{ heights within colours }} \\
\hline & \multicolumn{2}{|c|}{ Height $\times$ colour } & 1.6 & & & \\
\hline & \multicolumn{2}{|c|}{ Height $\times$ colour } & 1.2 & \multicolumn{3}{|c|}{ all other comparisons } \\
\hline
\end{tabular}

In both Experiments 1 and 2, cylinder traps set at $1200 \mathrm{~mm}$ caught more weevils than those set at $400 \mathrm{~mm}$. This may be due to factors such as fouling of the trapping surface with dust and wind blown debris, as well as to CRW flight behaviour. Fouling may have influenced the ability of the lower trapping surface to catch CRW by reducing trap stickiness and/or reflectance. Similar observations were recorded by Riley \& Schuster (1994) who observed that sticky traps placed near the soil surface rapidly became covered in wind-blown debris, which reduced their ability to capture pepper weevil (Anthonomus eugenii Cano (Coleoptera: Curculionidae)). A secondary effect of dust accumulation on a trapping surface is that it will alter its reflectance, thereby potentially altering any visual cues that adult CRW may be responding to. When CRW fly, they climb to heights greater than $1 \mathrm{~m}$ before moving horizontally. After flight, CRW rapidly drops back into the pasture canopy. Sustained flight immediately above the pasture is rarely if ever observed (S. Hardwick \& P.J. Gerard, unpubl. data). This flight pattern may make traps mounted at $1200 \mathrm{~mm}$ more likely to intercept CRW. Therefore, fouling and flight behaviour may have both caused the lower CRW catch recorded on cylinder traps mounted at $400 \mathrm{~mm}$ above the ground. In conclusion, yellow or white cylinder traps of a design similar to that used in previous studies of weevil flight activity in New Zealand pastures are suitable for monitoring CRW flights. 


\section{ACKNOWLEDGEMENTS}

The authors would like to thank Dave Saville, AgResearch Lincoln, for assistance with statistical analysis and Dr Pip Gerard and Dr Craig Phillips for their helpful comments on an early version of this manuscript.

\section{REFERENCES}

Barker GM, Pottinger RP, Addison PJ 1989. Flight behaviour of Listronotus bonariensis (Coleoptera: Curculionidae) in the Waikato, New Zealand. Environmental Entomology 18: 996-1005.

Barker GM, Addison PJ, Firth AC, Barratt BIP 1996. Sitona lepidus Gyllenhal newly established in New Zealand: assessment of distribution in the North Island. Proceedings of the 49th New Zealand Plant Protection Conference. Pp. 266-269.

Barratt BIP, Barker GM, Addison PJ 1996. Sitona lepidus Gyllenhal (Coleoptera: Curculionidae), a potential clover pest new to New Zealand. New Zealand Entomologist 19: 23-30.

Eerens JPJ, Hardwick S, Gerard PJ, Willoughby BE 2005. Clover root weevil (Sitona lepidus) in New Zealand: the story so far. Proceedings of the 67th New Zealand Grassland Association. Pp. 19-22.

Gerard PJ, Eden TM, Hardwick S, Mercer CM, Slay MWA, Wilson DJ 2007. Initial establishment of the Irish strain of Microctonus aethiopoides in New Zealand. New Zealand Plant Protection 60: 203-208.

Goldson SL, Frampton ER, Barratt BIP, Ferguson CM 1984. The seasonal biology of Sitona discoideus Gyllenhal (Coleoptera: Curculionidae), an introduced pest of New Zealand lucerne. Bulletin of Entomological Research 74: 249-259.

Goos M, Deptuch S, Faligowska K 1976. Introductory studies on collecting insects using coloured traps in field experiments. Polskie Pismo Entomologiczne 46: 829-834.

Hardwick S, Addison PJ, Eerens JPJ, Gerard PJ, Willoughby BE 2004. Factors influencing the rate of spread and impact of clover root weevil (Sitona lepidus Gyllenhal) (Coleoptera: Curculionidae) in New Zealand. Proceedings of the 8th Australasian Grasslands Invertebrate Ecology Conference. Pp. 147-154.

Hunt DWA, Raffa KF 1991. Orientation of Hylobius pales and Pachylobius picivorus (Coleoptera Curculionidae) to visual cues. Great Lakes Entomologist 24: 225-229.

Kalleshwaraswamy CM, Jagadish PS, Puttaswamy S 2006. Standardisation of food bait, height and colour of the trap for attracting red palm weevil, Rhynchophorus ferrugineus (Oliver) by synthetic pheromone lure. Annals of Plant Protection Sciences 14: 17-21.

Kirk WDJ 1984. Ecologically selective coloured traps. Ecological Entomology 9: 35-41.

Láska P, Zelenková I, Bicík V 1986. Colour attraction in species of the genera: Delia (Diptera, Anthomyiidae), Ceutorhynchus, Meligethes and Phyllotreta (Coleoptera: Curculionidae, Nitidulidae, Chrysomelidae). Acta Entomologica Bohemoslovaca 83: 418-424.

Nakamoto Y, Kuba H 2004. The effectiveness of a green light emitting diode (LED) trap at capturing the West Indian sweet potato weevil Euscepes postfasciatus (Fairmaire) (Coleoptera: Curculionidae) in a sweet potato field. Applied Entomology and Zoology 39: 491-495.

Phillips CB, McNeill MR, Hardwick S, Vink CJ, Kean JM, Ferguson CM, Winder LM, Iline II, Barron MC, Stuart B 2007. Clover root weevil in the South Island: detection, response and current distribution. New Zealand Plant Protection 60: 209-216.

Pottinger RP 1966. Observations on the flight activity of stem weevil Hyperodes bonariensis Kuschel in Canterbury. Proceedings of the 19th New Zealand Weed and Pest Control Conference. Pp. 186-196. 
Prokopy RJ, Owens ED 1983. Visual detection of plants by herbivorous insects. Annual Review of Entomology 28: 337-364.

Riley DG, Schuster DJ 1994. Pepper weevil adult response to colored sticky traps in pepper fields. South Western Entomologist 19: 93-107.

Smart LE, Blight MM, Hick AJ 1997. Effect of visual cues and a mixture of isothiocyanates on trap capture of cabbage seed weevil, Ceutorhynchus assimilis. Journal of Chemical Ecology 23: 889-902.

Stein W, Rezwani A 1973. Laboratory investigations of flight behaviour and readiness for flight in Sitona spp. (Col., Curculionidae). Anzeiger für Schadlingskunde, Pflanzen und Umweltschutz 46: 44-46.

Tedders WL, Mizell RF III, Wood BW 1996. Effects of color and trunk-wrap on pecan weevil catch in pyramidal traps. Journal of Entomological Science 31: 414-419. 